\title{
For improvement of catastrophic thinking and postoperative pain by using the video-based patient education
}

\author{
Yoshiyuki Hirakawa ${ }^{1,3}$, Michiya Hara ${ }^{2}$, Akira Fujiwara ${ }^{2}$, Hirohumi Hanada ${ }^{2}$, \\ Junichi Toita ${ }^{1}$, Yuki Hiraga ${ }^{1}$, and Shu Morioka ${ }^{3}$ \\ ${ }^{1}$ Department of Rehabilitation, Fukuoka Rehabilitation Hospital \\ ${ }^{2}$ Department of Orthopedics, Fukuoka Rehabilitation Hospital \\ ${ }^{3}$ Graduate School of Health Science, Kio University
}

\begin{abstract}
We previously reported on how patients catastrophize pain after total knee arthroplasty (TKA), indicating the importance of patient education in preventing pain catastrophizing. This study aimed to examine whether patient education reduces postoperative pain catastrophizing and to assess the effectiveness of video-based postoperative patient education.

TKA was performed at the Fukuoka Rehabilitation Hospital between October 2012 and December 2013. We established a control group comprising patients who had undergone TKA between October 2012 and December 2013 and underwent normal postoperative rehabilitation, and a video group comprising TKA patients who had undergone TKA between June 2013 and December 2013 and underwent preoperative and postoperative (3 and 5 weeks postoperatively) patient education in addition to their normal rehabilitation. Their education comprised a 7 -minute video, followed by an explanation by their physical therapist (PT), who also provided appropriate responses to the patients' questions. The video covered topics such as early-stage postoperative rehabilitation (expanding range of motion and muscle strengthening), and indoor and outdoor walking practice, as well as showed actual patients undergoing rehabilitation. The pain catastrophizing scale (PCS) was used to assess preoperative and postoperative ( 3 and 5 weeks after surgery) pain catastrophizing, and the numerical rating scale (NRS) was used for postoperative assessments. The total PCS score was defined as the sum of PCS scores in the following subscales: rumination, helplessness, and magnification. The validity of the differences in PCS and visual analog scale scores was compared using 2-way analysis of variance and post hoc Bonferroni correction. The statistical significance level was set at $<5 \%$.

No significant differences in preoperative and postoperative total PCS scores or in the PCS scores in the magnification and helplessness subscales
\end{abstract}


in both postoperative periods were noted between the two groups. However, the video group had significantly lower PCS scores for rumination in both postoperative periods. In addition, the video group generally had significantly lower pain scores at postoperative 5 weeks.

Based on our findings, patients may concretely predict their pain by viewing the video provided by their PT during patient education. The video may reflect whether patients should allow their psychological condition to dictate their physical functions, given their present pain or condition. The influence of the patient's psychological condition may be related to pain alleviation at postoperative 5 weeks. Thus, video-based patient education is an effective modality for stabilizing patients' postoperative psychological conditions and alleviating postoperative pain.

Keywords

Total knee arthroplasty (TKA); Postoperative pain; Pain catastrophizing; Education; Video

Received: 17 November 2014

Accepted: 17 June 2015

\section{ビデオを用いた患者教育による術後痛および破局的思考の改善効果}

平川善之 $1,3 /$ 原 道也 $2 /$ 藤原 明 $2 /$ 花田 弘文 ${ }^{2}$

問田 純一 $1 /$ 平賀 勇貴 $1 /$ 森岡 周 3

1 福岡リハビリテーション病院 リハビリテーション部

2 福岡リハビリテーション病院 整形外科

3畿央大学大学院 健康科学研究科

\section{はじめに}

\section{人工膝関節置換術（TKA）は主として変形性} 膝関節症などの膝痛の改善を目的になされる手 術であり，その術後リハビリテーション（術後 リハ）を実施する上で術後痛の程度は術後リハ の成果を左右する非常に重要な要素となる。 TKA の満足度は本邦において $74 \%$ との報告が あり ${ }^{8)}$ ，一定の成果を収めている手術ではある が, この満足度に術後痛の残存は強く影響を与
える 2,13$)$ 。一方 TKA の術後痛に関し，その $15 \%$ ほどが慢性化するとの報告がある1)。我々 はこれまでTKAの術後痛の強度やその予後に 痛みの破局的思考 (pain catastrophizing) が関 与することを報告した 7,22$)$ 。の破局的思考と は痛みの経験を否定的にとらえる傾向を示し， この破局的思考の傾向が強いと様々な障害が生 じることが指摘されており ${ }^{14)}$, 痛みの慢性化 モデル (fear avoidance model) の重要な要因と されている9)。Pain catastrophizing は Pain Catastrophizing Scale (PCS) により評価を行っ 
たが，その下位項目である反芻 (rumination) が 特に術後痛との関連があることがわかった。反 舓とは痛みに関連した考えに過剩に注意を向 け，痛みに固執した状態である19)。Sullivan ら 20)は，軟部組織損傷患者の痛みに rumination が関与していることを示した上で，その 対応として痛みに固執させない患者教育が重要 であると報告している。

我々はこの痛みへの固執した状態が，痛みの 予後を悲観的に捉えることになり，過度な不安 が形成され，術後痛の強度に関与するのではな いかと考えた。そこで今回，現状の痛みへの固 執と予後への不安を改善することを目的とし て，術後リ八の流れを示したビデオを作成し， 術後経過をビデオ鑑賞と口頭説明を加えること で詳細に提示する活動を行った。本研究では, この活動により痛みへの固執が軽減し，患者の 抱える不安の減少とともに術後痛が軽減される のかを検討することを目的とした。

\section{対 象}

対象は福岡リハビリテーション病院にて 2012 年 10 月から 2013 年 12 月までに TKA を 施行された患者を包含基準とし，除外基準を研 究の趣旨を理解できない者, 神経損傷など重篤 な術後合併症を有した者, 精神疾患を有する 者，再置換術など複数回の TKA を実施した者 とした。

これらの条件をもとに，2012 年 10 月から 2013 年 5 月に TKA を施行した者 31 名を対照 群とし， 2013 年 6 月から 2013 年 12 月に TKA を施行した者 31 名をビデオ群とした。研究デ ザインは非無作為化比較対照試験とした。各群
Table 1 Sample characteristics

\begin{tabular}{lcc}
\hline characteristics & $\begin{array}{c}\text { control group } \\
(n=31)\end{array}$ & $\begin{array}{c}\text { video group } \\
(n=31)\end{array}$ \\
\hline & $2012.10 \sim 2013.5$ & $2013.6 \sim 2013.12$ \\
\hline Age (year) & $75.3 \pm 6.9$ & $74.7 \pm 6.3$ \\
Gender & & \\
Male & 5 & 5 \\
Female & 26 & 26 \\
Laterality & & \\
Right & 16 & 18 \\
Left & 15 & 13 \\
\hline
\end{tabular}

の特性を Table 1 に示す。

なお，本論文を作成するにあたり，筆者が所 属する福岡リハビリテーション病院倫理審查委 員会による承認（FRH-R-0008）を得た。

\section{方法}

\section{1. 術後リハビデオについて}

今回の研究で使用したビデオは, 7 分間ほど の内容で, 術後経過に沿った患者の状態と実際 の術後リハの内容を示したものである。その詳 細は, 術後経過の中で術後痛がどのように低下 していくのか経過を示したもの, 術後早期や疼 痛憎悪時に行うアイシングなどの患部管理の方 法, 筋力強化訓練や術側膝関節の可動域訓練, 平行棒内での歩行訓練, 杖での歩行訓練, プー ル内でのリハビリテーション, 階段昇降や家事 動作訓練などの日常生活訓練などである。これ 
らの内容を術後の時期別に区切り提示すること で，退院までの経過がたどれるように作成し た。これによりどのように術後回復が得られる か提示し，短期的な将来の予測が具体的に想像 できるような内容とした。また同時に術後りハ の目的や，術後リ八の進行とともに痛みの増悪 する時期もあるが徐々に低下していくこと，患 者の状態に合わせて術後り八を進めていくこと などを口頭にて説明を加えた。

また実際の患者と Physical Therapist (PT) が 出演し, 実際に行っている風景を撮影した。出 演した患者にはこのビデオの内容と目的を口頭 にて説明し，撮影に関する同意を得て行った。

\section{2. 評価項目}

対照群, ビデオ群ともに術前, 術後 3 週, 術 後 5 週の各時期に術後痛の評価を Numerical Rating Scale（NRS）を用い，痛みの破局的思考 をPCSにて評価した。PCS はPain Catastrophizing Scale 日本語版 ${ }^{14)}$ を用いて評 価した。これは 13 項目の質問から構成される 自己記入式の評価尺度である。具体的な質問項 目は，(1) 痛みが消えるかどうか, ずっと気に している。(2)もう何もできないと感じる。(3) 痛みはひどく，決して良くならないと思う。(4) 痛みは恐ろしく, 痛みに圧倒されると思う。(5) これ以上耐えられないと感じる。(6) 痛みがひ どくなるのではないかと怖くなる。(7)他の痛 みについて考える。(8)痛みが消えることを強 く望んでいる。(9)痛みについて考えないよう にすることはできないと思う。10 どれほど痛 むかということばかり考えてしまう。(11) 痛み が止まってほしいということばかり考えてしま う。(12) 痛みを弱めるために私にできることは 何もない。13 何かひどいことが起こるのでは ないかと思う。というものである。これらを普
Table 2 Rehabilitation protcol of total knee arthroplasty

\begin{tabular}{lc}
\hline \multicolumn{1}{c}{ day } & protcol \\
\hline preoperation & assessment \\
postoperative 1 day & Physical Therapy start \\
postoperative 1 week & Walker gait \\
postoperative 3 weeks & T cane gait \\
postoperative 5 weeks & discharge \\
\hline
\end{tabular}

段痛みを感じている自分の状態にどの程度当て はまるのか各項目 5 件法（0：全くあてはまら ない〜4: 非常にあてはまる) で回答し, 総計 および下位項目得点が高いほど破局的思考が強 いことを示す。さらに上記質問項目において(1) (8)(9)1011)反萢, (2)(3)(4)(12)を無力感，(6)(7)13) を拡大視の 3 つの下位項目に分類される。本研 究に打いても PCS 総計, 反鴷, 拡大視, 無力 感に分類して分析に用いた。NRS は全く痛み を感じない状態を 0 とし, 今までに自分が経験 した最高の痛みを 10 として, 現在の痛みの程 度を自己記入式にて評価した（11 件法，0：痛 みなし〜10：耐えられない痛み)。ビデオ群の 評価はビデオ鑑賞後に評価を実施した。

\section{3. 研究手順}

対照群は当院 TKA 術後プロトコール (Table 2)に従って通常の術後リ八を実施した。その 詳細は，手術前日に術前評価を行い，術後 1 日 より理学療法が開始されアイシングなどの患部 管理と関節可動域の拡大, 筋力の回復を図りつ つ平行棒内歩行訓練を開始, 術後 1 週で歩行 器, 術後 3 週で $\mathrm{T}$ 字杖へ移行し, 術後 5 週で 退院を目指すものである。 
(A) PCS total

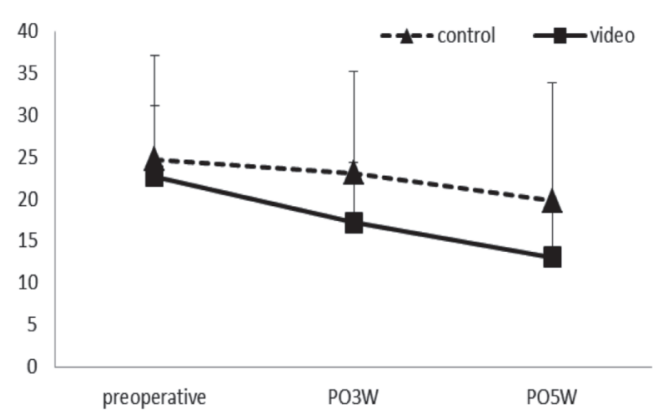

(C) helplessness

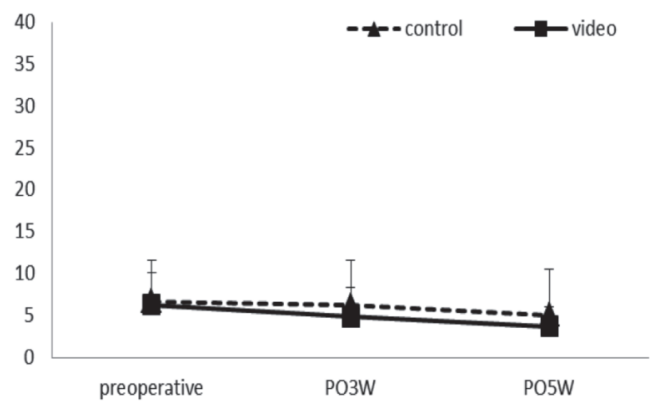

(B) rumination

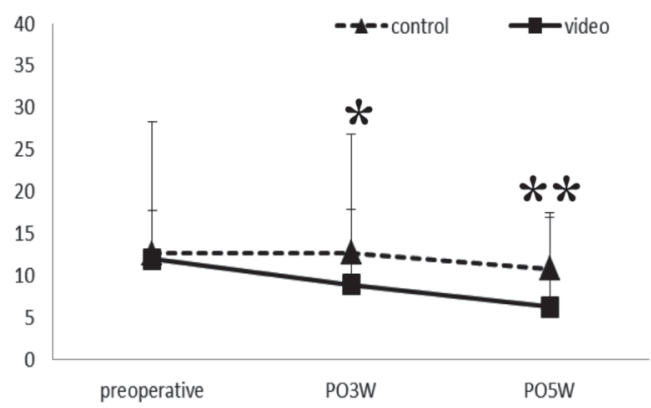

(D) magnification

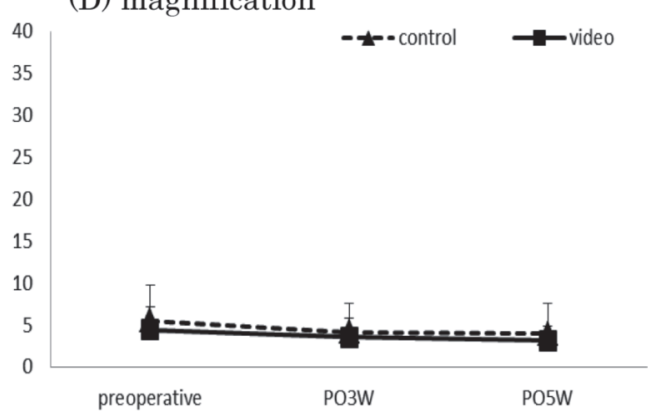

Fig.1 Results of pain catastrophizing scale.

Video group showed a significantly lower value in rumination on PO3W $(p<0.05)$ and PO5W $(p<0.01)$ evaluated by PCS. PO3W $=$ postoperative 3 weeks, PO5W $=$ postoperative 5 weeks. ${ }^{*} p<0.05,{ }^{* *} p<0.01$

ビデオ群は対照群と同様に通常の術後リハを 行い, それに加えて術前, 術後 3 週, 術後 5 週に術後リハビデオを鑑賞しつつ，担当 PT が その内容を口頭にて説明した。

統計学的分析手法は, 術前, 術後 3 週, 術後 5 週の各時期に, 対照群・ビデオ群の両群間で, PCS (総計, 反焬, 拡大視, 無力感) と NRS それぞれの差の検定を 2 元配置分散分析および post hoc として Bonferroni 法を用いて比較し た。統計学的有意水準を $5 \%$ 未満とした。

\section{結＼cjkstart果}

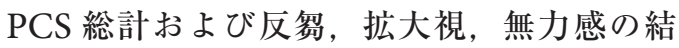

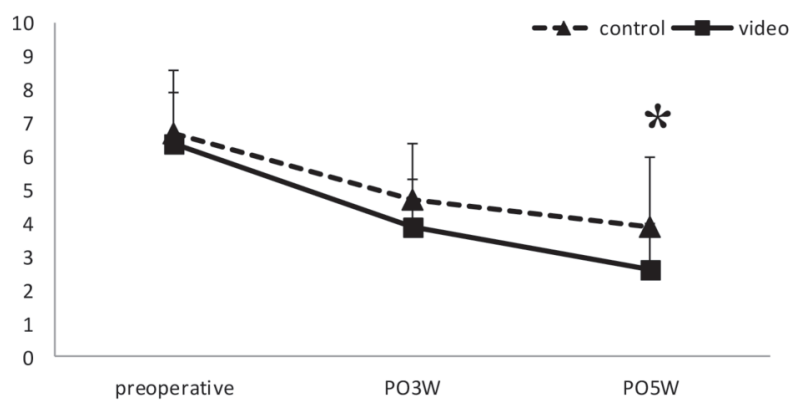

Fig.2 Results of pain.

Video group showed a significantly lower value on PO5W evaluated by NRS. PO3W = postoperative 3 weeks, PO5W $=$ postoperative 5 weeks. ${ }^{*} p<0.05$

果を Fig.1 に示す。PCS 総計における両群間の 比較では, 術前, 術後 3 週, 術後 5 週のいず れの時期においても両群間に有意な差はなかっ た。同様にPCS の下位項目である拡大視や無 
力感に関しても，いずれの時期においても両群 間に有意な差はみられなかった。しかし反敂の 両群間の比較では, 術前には差がないものの, 術後 3 週 $(p<0.05)$ 術後 5 週 $(p<0.01)$ にビデオ 群が有意に低い結果となった。

次に術後痛の結果を Fig.2 に示す。術後痛に おける両群間の比較では, 術前および術後 3 週 には両群間に差はなかったが, 術後 5 週にビデ オ群が有意に低い結果となった $(p<0.05)$ 。

\section{考察}

今回術前, 術後 3 週, 術後 5 週の各時期に 実際の術後リハの流れを鑑賞しつつ担当 PT が 説明を行うことで, 術後 3 週および 5 週の反 夠と術後 5 週の術後痛の軽減がみられた。

反颎とは痛みへ過剩に固執した状態で，その 結果痛みの予後を悪い方向へ予測してしまう傾 向を示す。今回予後を示したビデオを提示しつ つ担当 PT が説明を加えることで, 術後早期の 機能的な回復時期に, 具体的に先の予測ができ るようになり，現在の痛みや現時点での身体機 能の否定的側面に固執する心理状態に至らな かったのではないかと考えられる。当目ら21) は Total Hip Arthroplasty (THA) 患者を対象 に入院前患者教育により疾患を理解させ, 経験 するであろう出来事に予測をつけることで準備 性が高まり, 結果的に心理的安定がはかれるこ とが予測されると報告している。今回の結果か ら，ビデオにより今後経験する術後リハの内容 を理解し予測できるようになることにより，固 執から不安感が生じる必然性がなくなり，その 後の痛みの軽減につながったと考えられた。 Ploghaus ら 16) は不安刺激を与えることで海馬
や midinsula の活動が光進し, 痛み感覚が増悪 することを示したうえで，正確な情報をあたえ 治療への準備を的確にすることにより疼痛の軽 減や慢性化の予防になる可能性を示唆してい る。また Sjöling ら ${ }^{17)}$ は有意義な情報提供によ り, 患者に能動的な治療参加を促した結果, 不 安の軽減と術後痛の改善が早くなったことを報 告している。このことから正確で有意義な情報 提供によって, 痛みへの固執化と破局的思考を 低下させることにより術後痛の慢性化の予防に なる可能性がある。

しかし患者教育や情報提供による不安感など の精神機能への影響や, 術後痛への効果につい ては様々な報告がある。Doering ら ${ }^{3)}$ は THA 患者に対し手術前日の夕方に, 手術直前・直後 の周術期ケアの流れを中心に示したビデオを鑑 賞する群としない群の 2 群間で, 術後 5 日ま での不安感と鎮痛薬の消費量, 術後痛の推移を 比較し, ビデオ鑑賞により不安感と鎮痛薬の消 費量は減少したが, 術後痛には両群間に差はな かったとしている。また McDonaldら 15) は人 工関節置換術患者に対する, 不安感や術後痛, 運動機能, 入院期間, 合併症などへの患者教育 の効果をレビューにより検証し, 不安感には効 果があるが術後痛の程度や入院期間には効果が 低いとしている。また Gocen ら ${ }^{5)}$ は Total Hip Replacement（THR）患者に対し, 術後のリハ やADL（トイレ，入浴方法，階段昇降など）を 示したビデオを術前に見せる患者教育を行った 群と行わなかった群を比較し, 術後の ADL score（Harris Hip Score）は患者教育群が有意 に改善したが，退院時の安静扔よび運動時痛に は両群間に差がなかったと報告している。本研 究に打いては, 術前, 術後 3 週, 術後 5 週に ビデオ鑑賞を行い, 術後 3 週で反儆の軽減が認 められている。この TKA 術後 3 週では, 多く 
の患者は歩行形態が杖歩行に移行し，活動量が 増加することから術後痛の一時的な増悪がみら れる。このことから「このまま歩いていいのか」 「本当に治るのか」「しっかりと歩けるようにな るのか」といった不安を訴える患者は多い。こ ういった不安感が現時点の痛みを否定的に捉え ることから破局的思考を強め, さらに痛みに固 執させることが予想される。今回はこういった 心理状態にある患者に対し, 痛みへの対処法と 正確な予後を提示する患者教育を行えたことか ら，その時点での反鄒の軽減となり，これが術 後 5 週での反鴷や術後痛の軽減につながったと 考えられた。これまでの患者教育や情報提供に よる術後痛への改善効果に関する研究報告で は，対象とする疾患が異なり，また教育実施時 期や効果判定時期が異なるため比較は困難であ るが，有効な患者教育とは，患者の病期や心理 状態に合わせた教育の適切な時期を考慮する必 要があり，また患者の求める教育・情報内容で あることが，その成果を決定する要因になると 思われた。Haines ら 6) は術間際の患者教育は, 患者の不安が強く教育には不適切な時期であり としており，またLévesque ら 10)は与えられた 情報を忘れやすい傾向にあると報告がある。今 回術前にもビデオ鑑賞による情報提供と患者教 育を実施したが，その時点ではビデオ群と対照 群間には各測定項目に差はみられていない。ま た今回は術前後に合計 3 回, 同様の内容のビデ オを鑑賞したが，中には術前に鑑賞したことを 忘れている患者が数名存在した。このことから 患者の心理状態を考慮し，患者がその時々に必 要としている情報や教育を適切に提供すること で，患者教育の有効性はより高くなると考えら れた。

また今回は実際の患者と PT が出演するビデ オを媒体とし, それを鑑賞しつつ PT が説明を
加え, 患者からの質問に応える形式で行った。 Snyder-Ramos ら 18）は全身麻酔前の患者 197 名に対し，通常の口頭術前説明，パンフレット と口頭説明, ビデオと口頭説明の 3 群で患者満 足度と理解度を調查した結果, ビデオと口頭説 明群が満足度・理解度とも高かったとしている。 またDone ら ${ }^{4)}$ は全身麻酔前にビデオによる説 明を加えることでより術前の不安が軽減するこ とからビデオは有効な情報提供ツールであると している。今回の結果からもビデオを用いつつ 治療者が口頭説明を加える方法は, 患者の理解 を向上させる有効な患者教育方法であると思わ れた。

近年，患者教育の教育内容に関し，神経生理 学的な教育内容の有効性が報告されている。 Louw らは腰椎神経根症状の患者に対し, 解剖 学や病理学に基づく教育の効果は限界があり, 神経生理学的な教育の有効性を報告し ${ }^{12)}$ ，ま た筋骨格障害患者に対し, その痛みや能力障 害, 破局的思考に pain science に基づく教育が 効果的であると報告している11)。今回の結果 からは内容に関する議論には至らないが, 患者 が何を求めているのか, 患者はどのような心理 状態にあるのかを十分に評価し, 患者個人個人 に合わせた教育内容を設定する必要があるので はないかと思われた。

本研究から, TKA 術後患者において, 術後 痛に不安感を強く持つことにより破局的思考が 生じる時期に, 今後の痛みの経過や機能回復の 過程を示したビデオを鑑賞しつつ説明を加える ことで, 術後痛への否定的な感情や固執感を低 下させ, 術後痛の軽減につながったと考えられ る。特に「本当に痛みが減少するのか」「しっ かりと歩けるようになるのか」といった患者の 抱える具体的な不安要素に対し, 患部の管理方 法や歩行能力が向上する過程を教育内容に組み 
込めたことが有効な患者教育につながったと考 えられた。

本研究の限界として, 今回ビデオ群と対照群 に群分けを行ったが, しかし両群とも術者や術 後プロトコールは同じであるが，倫理的な配慮 から Randomized Control Trial (RCT) の研究 デザインはできなかった点が挙げられる。また ビデオ群にも反鴷や術後痛が強い症例も散見さ れる。こういった患者に対する考察やその対策 に関し検討ができていない点が考えられる。こ れらは今度の課題となると考えている。

\section{結語}

TKA 患者に対し, 術前, 術語 3 週, 術後 5 週に術後リハの流れを示したビデオを鑑賞し， 担当 PT が説明や質疑応答を行う患者教育を実 施した。その結果術後 3 週の反䀛と術後 5 週 の反㱀抢よび術後痛の有意な改善が認められ た。ビデオによる情報提供と担当 PT による患 者教育は，患者の心理状態を考虑した実施時期 と，患者の求める情報を組み込んだ内容にする ことにより, 術後患者の心理状態の安定と術後 痛の軽減に有効な手段になると思われた。

\section{文 献}

1) Ackerman, I.N., Graves, S.E., Wicks, I.P., Bennell, K.L., Osborne, R.H., Severely compromised quality of life in women and those of lower socioeconomic status waiting for joint replacement surgery, Arthritis Rheum., 53 (2005) 653-658.

2) Dickstein, R., Heffes, Y., Shabtai, E.I., Markowitz, E., Total knee arthroplasty in the elderly: patients' self-appraisal 6 and 12 months postoperatively, Gerontology, 44 (1998) 204210.
3) Doering, S., Katzlberger, F., Rumpold, G., Roessler, S., Hofstoetter, B., Schatz, D.S., Behensky, H., Krismer, M., Luz, G., Innerhofer, P., Benzer, H., Saria, A., Schuessler, G., Videotape preparation of patients before hip replacement surgery reduces stress, Psychosom. Med., 62 (2000) 365-373.

4) Done, M.L, Lee, A., The use of a video to convey preanesthetic information to patients undergoing ambulatory surgery., Anesth. Analg., 87 (1998) 531-536.

5) Gocen, Z., Sen, A., Unver, B., Karatosun, V., Gunal, I., The effect of preoperative physiotherapy and education on the outcome of total hip replacement: a prospective randomized controlled trial, Clin. Rehabil., 18 (2004) 353358.

6) Haines, N., Viellion, G., A successful combination: preadmission testing and preoperative education, Orthop. Nurs., 9 (1990) 53-57.

7) 平川善之, 原道也, 藤原明, 花田弘文, 森岡周, 術後痛の慢性化に影響する認知的・精神的因 子の検討, Pain Research, 28 (2013) 24-32.

8) Hosaka, K., Saito, S., Ishii, T., Mori, S., Sumino, T., Tokuhaski, Y., Asian-specific total knee system: 5-14 year follow-up study. BMC Musculoskelet. Disord,, 12 (2011) 251.

9) Lethem, J., Slade, P.D., Troup, J.D., Bentley, G., Outline of a fear-avoidance model of exaggerated pain perception-I, Behav. Res. Ther., 21 (1983) 401-408.

10) Lévesque, L., Grenier, R., Kérouac, S., Reidy, M., Evaluation of a presurgical group program given at two different times, Res. Nurs. Health., 7 (1984) 227-236.

11) Louw, A., Diener, I., Butler, D.S., Puentedura, E.J., The effect of neuroscience education on pain, disability, anxiety, and stress in chronic musculoskeletal pain, Arch. Phys. Med. Rehabil., 92 (2011) 2041-2056.

12) Louw, A., Butler, D.S., Diener, I., Puentedura, E.J., Development of a preoperative neuroscience educational program for patients with lumbar radiculopathy, Am. J. Phys. Med. Rehabil., 92 (2013) 446-452.

13) Matsuda, S., Kawahara, S., Okazaki, K., Tashiro, Y., Iwamoto, Y., Postoperative alignment and ROM affect patient satisfaction after TKA, Clin. Orthop. Relat. Res., 471 (2013) 127-133.

14）松岡紘史, 坂野雄二, 痛みの認知面の評価: Pain Catastrophizing Scale 日本語版の作成と 信頼性および妥当性の検討, 心身医学, 47 (2007) 95-102. 
15) McDonald, S., Hetrick, S., Green, S., Preoperative education for hip or knee replacement, Cochrane Database Syst. Rev., 1 (2004) CD003526.

16) Ploghaus, A., Narain, C., Beckmann, C.F., Clare, S., Bantick, S., Wise, R., Matthews, P.M., Rawlins, J.N., Tracey, I., Exacerbation of pain by anxiety is associated with activity in a hippocampal network, J. Neurosci., 21 (2001) 9896-9903.

17) Sjöling, M., Nordahl, G., Olofsson, N., Asplund, K., The impact of preoperative information on state anxiety, postoperative pain and satisfaction with pain management, Patient Educ. Couns., 514 (2003) 169-176.

18) Snyder-Ramos, S.A., Seintsch, H., Böttiger, B.W., Motsch, J., Martin, E, Bauer, M., Patient satisfaction and information gain after the preanesthetic visit: a comparison of face-to-face interview, brochure, and video, Anesth. Analg., 100 (2005) 1753-1758.
19) Sullivan, M.J.L., Bishop, S.R., Pivik, J., The pain catastrophizing scale: Development and validation, Psychol. Assess., 7 (1995) 524532 .

20) Sullivan, M.J., Stanish, W., Waite, H., Tripp, D.A., Catastrophizing pain and disability in patients with soft-tissue injuries, Pain, 77 (1998) 253-260.

21）当目雅代，人工股関節全置換術における入院 前患者教育の実施と評価, 日本看護科学会誌, 24 (2004) 24-32.

22) Hirakawa, Y., Hara, M., Fujiwara, A., Hanada, H., Morioka, S., The relationship between psychological factors, neglect-like symptoms, and postoperative pain after total knee arthroplasty, Pain Res. Manag., 2014 in press.

Address for correspondence: Yoshiyuki Hirakawa Department of Rehabilitation, Fukuoka Rehabilitation Hospital 7-770 Nokata, Nishi-ku, Fukuoka 819-8511, Japan 